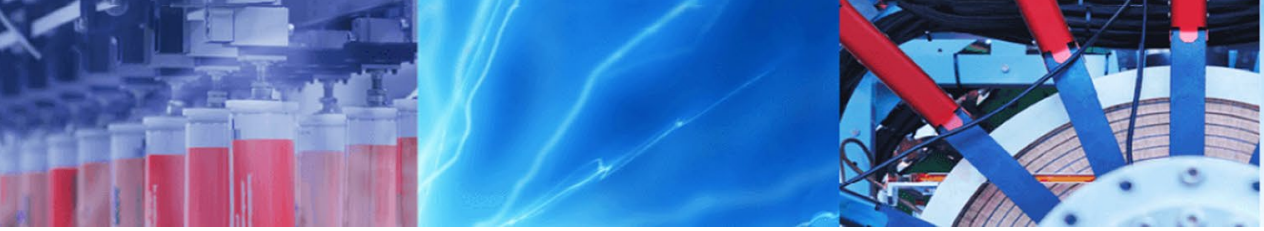

Research Article

\title{
Effect of microrelief and water-table on vegetation dynamics in silty loam saline soils of coastal areas
}

\author{
Mohammad Mansouri ${ }^{1} \cdot$ Seyed Akbar Javadi ${ }^{1} \cdot$ Mohammad Jafari $^{2} \cdot$ Hossein Arzani $^{2}$
}

Received: 30 October 2020 / Accepted: 2 February 2021 / Published online: 27 February 2021

(c) The Author(s) $2021 \quad$ OPEN

\begin{abstract}
Microrelief (MR) and water-table (WT) severely influence plant communities formation and development in silty loam saline soils of coastal areas. This research aimed to investigate the effect of MR and WT fluctuations on the dynamics of vegetation in coastal silty loam saline soils of southern Iran. Soil characteristics, vegetation structure and composition were investigated through the growing season, and obtained data were submitted to a canonical correspondence analysis. Based on the results, MR $(\min =0.5 \mathrm{~m}$ and $\max =1.0 \mathrm{~m})$ and $\mathrm{WT}(\max =1 \mathrm{~m})$ fluctuations significantly changed both structure and floristic composition through change in soil characteristics (Sig. $<0.05$ ). Factors of soil moisture content, SAR and Na severely changed under MR and WT fluctuations and received new eigenvalues through the year. Our results demonstrated that a minimum change in MR and/or WT influence soil properties and vegetation structure and composition in silty loam saline soils of coastal areas.
\end{abstract}

Keywords Coastal areas · Land management · Plant communities · Saline habitats · Vegetation characteristics

\section{Introduction}

Micro-relief (MR) and water-table (WT) significantly influence vegetation dynamics in silty loam saline soils of coastal areas. In fact, MR and WT fluctuations affect vegetation by change the physical and chemical properties of the soil [1, 2]. Generally, physiochemical soil attributes, i.e., N, P, K, EC, pH influence the vegetation [3]; however, such these changes will vary depending on the region, topography, climate and edaphic factors.

MR heterogeneity which is also called micro-pain, micro-topography and micro-elevation can lead to substantial variability in microclimate and hence niche opportunities [4] and creates microsites for vegetation [5, 6]. In fact, only a few centimeters is enough to change ecosystem function in terms of physical, chemical and biological characteristics [7-9]. In general, MR and WT fluctuations influence vegetation through change the soil variables [10, 11]. These changes play important implications for nutrient flow for vegetation even for local terrestrial plants at regional scales [12-16] where MR may completely influence the dynamics of vegetation [17].

WT fluctuations also create hydrological stresses [18, 19], control the balance of anaerobic and aerobic processes $[20,21]$ and finally change the physical and chemical properties of soils [22]. WT may fluctuate at different time scales, from the seasonal to the daily that can influence plant growth and development [23].

The coastal saline and heavy soils of arid and semiarid regions are one of the most strategic regions in the world where millions of people live [24]. In these areas, MR and WT changes have severe negative/positive effects on vegetation. Generally, heavy soils often have problems for plants such as salt accumulation [25] and therefore,

$\triangle$ Seyed Akbar Javadi, a.javadi@srbiau.ac.ir; Mohammad Mansouri, m.mansouri4561@gmail.com;

Mohammad Jafari, jafary@ut.ac.ir; Hossein Arzani, h.arzani@ut.ac.ir| ${ }^{1}$ Department of Forest, Range and Watershed Management, Faculty of Natural Resources and Environment, Science and Research Branch, Islamic Azad University, Tehran, Iran. ${ }^{2}$ Department of Reclamation of Arid and Mountainous, Faculty of Natural Resources, University of Tehran, Karaj, Iran. 
changes in MR and WT in saline and heavy soils play an important and vital role in the dynamics of vegetation [1].

Overall, many studies have quantified the vegetation dynamics and its correlation with environmental variables [8-10, 14]; however, there is no information about the vegetation changes in relation to MR and WT fluctuations in silty loam saline soils of coastal areas in arid environments. We investigated the vegetation characteristics in relation to soil properties under MR and WT fluctuations in silty loam saline soils, in coastal areas of southern Iran.

\section{Materials and methods}

\subsection{Study area}

The study was carried out in saline habitats of Gachin (Hormozgan province, southern Iran) during 2018-2019. Gachine is a wide coastal plain (Mud flat) with an area of 23,237.5 hectares located in the west of Bandar Abbas between the Persian Gulf and Omman sea (of $55^{\circ} 44^{\prime} 48^{\prime \prime}$ $\mathrm{E}$ to $27^{\circ} 01^{\prime} 44^{\prime \prime} \mathrm{N}$ ) (Fig. 1). The minimum and maximum elevation of the area are 5 and $63 \mathrm{~m}$ (northern hills of the region) above sea level. The average annual rainfall of the region is $98 \mathrm{~mm}$. This area has arid climate (Aridity index $=6.4$ ) with mild winters and plants growth begins with the winter rainfall and the period of plant growth continues from late February to September (According to the information of Hajiabad meteorological station).
Therefore, the study was conducted during April, June and September.

Based on the experiments, the area has silty loam saline soils with high WT especially in April and therefore creates an especial habitat conditions for the plant species. Tides usually do not affect the area and groundwater moves to the sea in the form of very slow subsurface currents after rainfall. This area is currently protected without livestock grazing.

\subsection{Measuring MR and WT}

Measurements were made using a systematic design through adjacent transects and placed plots [26]. For this purpose, four $1000 \mathrm{~m}$ liner transects were located $0.5 \mathrm{~km}$ apart, parallel on top of the plant's canopy and hummocks points through the area (parallel to the shoreline). 12 permanent plots (a total of 48 ) of $1 \times 2 \mathrm{~m}$ were established near to each transect line to identify plant species. Samplings were performed three times at April, June and September.

MR was measured along the transects to obtain relative distance above the general ground level [1]. For this purpose, the levels of flat points were assigned as benchmark level $(M R=0)$. Hummock and hollow points were identified and recorded based on the distance between the benchmark and the transect level [8].

The number of repetitions for MR was 4 through each transect (a total of 16 points). The maximum MR was
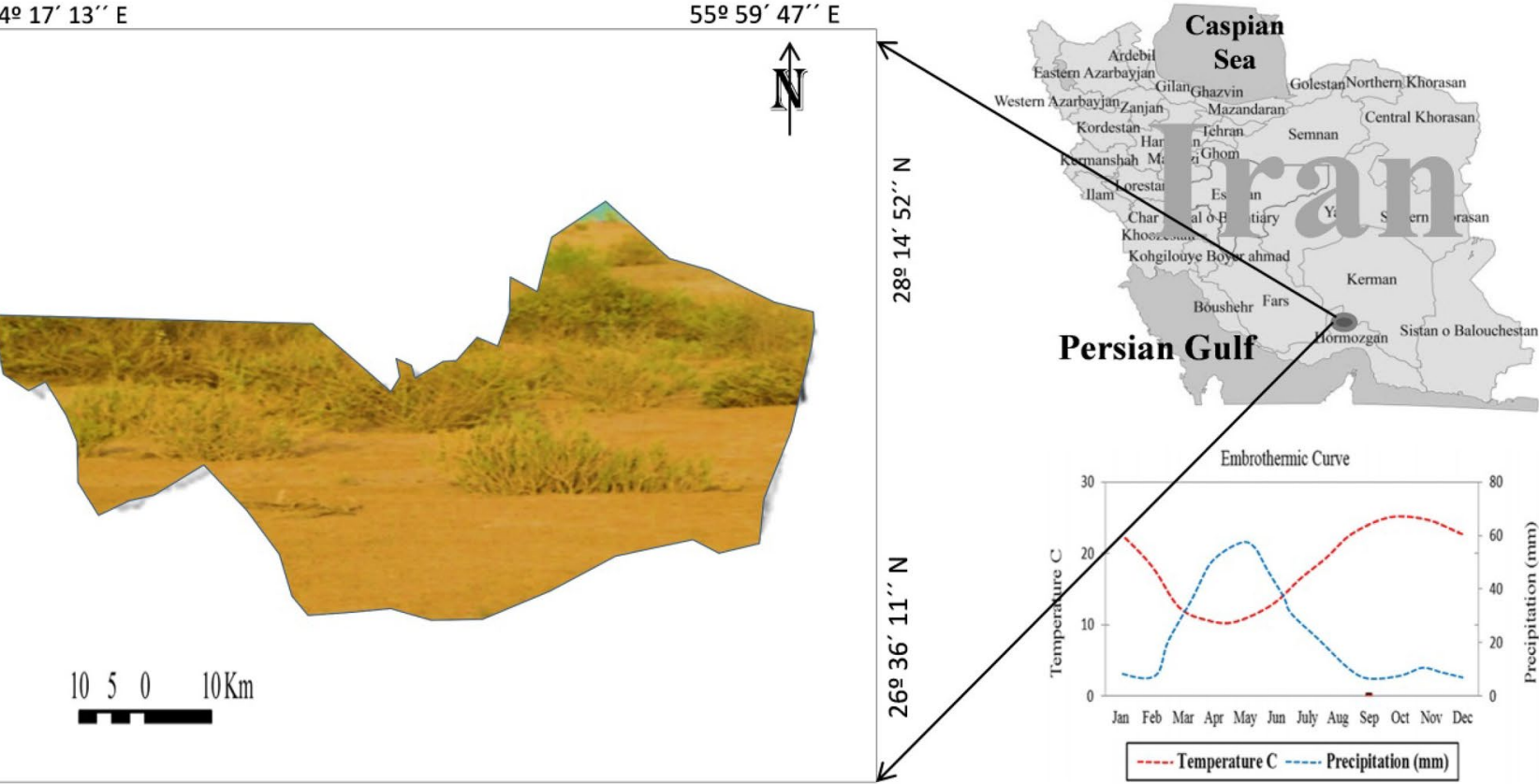

Fig. 1 Geographical location of the study area in southern Iran

\section{SN Applied Sciences}


$1.00 \mathrm{~m}$, which was considered to be in the range of $-50,+50$ and $+100 \mathrm{~cm}$ in relation to the benchmark level $(M R=0.0)$. A theodolite camera ( $\mathrm{TCNE}_{203}$ ) was also used to accurately calculate the MR along the transects.

WT changes also were studied along with MR measurements. For this purpose, 6 experimental wells dug through the first (no: 1) and last (no: 4) transects and WT was recorded. WT through the transects no 1 and 2 was measured according to the gradient of duged wells. At the beginning of the growing season, WT was equal to $0.5 \mathrm{~m}$ in benchmark level $(M R=0)$, then decreased to $1.0 \mathrm{~m}$ in the mid-growing season and finally reached to $1.5 \mathrm{~m}$ at the end of the growing season.

\subsection{Vegetation characteristics, richness and diversity}

Plant species were identified and recorded in plots three times at the beginning (April), middle (June) and end of the growing (September) season.

Cover and density of the all species were measured in plots. Cover was calculated based on the percentage of plot area covered by plant species. Density was also measured based on the count of plant stands in each plot. All species were also categorized in forbs and grasses, and a second classification also was made based on the life form of annual and perennial species.

Margalef richness index and Shannon diversity index were calculated as follows:

Margalef Index: $D=(S-1) / \operatorname{Ln} N$; Shannon Index: $E=\left(-\sum_{i=1}^{S} p i L n p i\right) / L n S(p i=\mathrm{Ni} / N)$; Where, $\mathrm{Ni}=$ the number of species $I, N=$ the total number of species, $S=$ the number of species present [27]; $d=$ Margalef Diversity Index, $S=$ Total number of species, $N=$ Total number of individuals [28].

\subsection{Soil characteristics}

Soil samples were randomly collected from 12 plots placed along transects from depths of $0-20$ and $20-80 \mathrm{~cm}$. Similar to vegetation, soil sampling performed three times in April, June and September as well. Factors of $\mathrm{pH}$, electrical conductivity (EC) and sodium adsorption ratio (SAR) based on soil/water ratio, potassium $(\mathrm{K})$, gypsum $\left(\mathrm{CaSO}_{4}\right)$, organic matter (OM), magnesium-calcium ( $\mathrm{MgCa}$ ), sodium $(\mathrm{Na})$, moisture content (MC), saturation percentage (SP) and total neutralizing value (T.N.V) were measured in soil laboratory of Islamic Azad university, Tehran.

\subsection{Data analysis}

Data were analyzed for normality. Detrended correspondence analysis (DCA) was used to find the general pattern in species distribution along the gradients. Data also submitted to a canonical correspondence analysis (CCA) to summarize variation in vegetation characteristics related to environmental variables using the PC-ORD. ANOVA and grouping test were performed to compare mean values of the vegetation characteristics using SPSS software; version 17.0.

\section{Results}

Table 1 shows a list of the plant species in the study area. Results on the floristic diversity of the area were categorized in family groups and life form as well. In general, the region has a relatively high plant diversity so that there are different types of annual and perennial plants with different life forms.

The results of DCA ordination indicated a reasonable separation of the species groups along the first and second axes (Fig. 2). During April, all plots mostly contain different species and almost all surfaces of the ground ( $>60 \%)$ was covered by vegetation. In June and September, however, new vegetation patterns were observed through the plots. In the DCA ordination diagram, the species tended to be grouped into the three plant communities. During the late growing season, in September, ordination showed more visible results (Fig. 2c). Based on the DCA ordination diagram at September, the first axis explained the greatest part of the floristic variation (Eigenvalue $=0.702$ ), indicating high variation in the composition and abundance and a clear unimodal response between species and WT changes. Also, the second DCA axis explained a smaller percentage of data variance to differentiate the groups (Eigenvalue $=0.512$ ). Generally, grass (i.e., B. squarrosa, Eremopyrom sp.) and non-grass (i.e., O. carduiformis, $S$. olivieri) species well separated and also some halophytes (i.e., H. salicornica, S. rozmarinus) showed a distinct group. The amount (percentage cover) and type of vegetation (life form) changed dramatically during the season. On the other hand, in this area, the groundwater level has fluctuated over time and the plants have adapted to these fluctuations so that in points with lower MR, halophytes are found in abundance. At the end of the season, grasses are more common in areas that are neither too high nor too low $(M R=0.5 \mathrm{~cm})$. The MR and WT fluctuations showed significant relationships with vegetation characteristics.

Table 2 shows mean value of soil variables for different vegetation groups in study area. Based on the results, some factors, i.e., $\mathrm{Na}, \mathrm{SAR}, \mathrm{EC}, \mathrm{MC}, \mathrm{SP}$ had the most 
Table 1 List of plant species in the study area

\begin{tabular}{|c|c|c|c|}
\hline Scientific name & Family & Life form & Halophyte \\
\hline Aegilops cylindrica Host. & Gramineae & Th & \\
\hline Aeluropus lagopoides (L.) Thwaites & Gramineae & $\mathrm{He}$ & * \\
\hline Alhagi persarum Boiss. \& Buhse & Papilionaceae & $\mathrm{He}$ & \\
\hline Amaranthus albus $\mathrm{L}$ & Amaranthaceae & Th & \\
\hline Allium sp. & Liliaceae & $\mathrm{Ge}$ & \\
\hline Alyssum desertorum Stapf & Crucifereae & Th & \\
\hline Anabasis setifera Moq & Amaranthaceae & $\mathrm{He}$ & * \\
\hline Artemisia sieberi Besser & Asteraceae & $\mathrm{Ch}$ & \\
\hline Atriplex micrantha Ledeb & Amaranthaceae & $\mathrm{Ch}$ & \\
\hline Atriplex leucoclada Boiss & Amaranthaceae & $\mathrm{Ch}$ & * \\
\hline Bassia eriophora (Schrad.) Asch & Amaranthaceae & Th & \\
\hline Boissiera squarrosa var. glabriflora (Boiss.) Bor & Gramineae & Th & \\
\hline Bothriochloa ischaemum (L.) Keng & Gramineae & Th & \\
\hline Carex stenophylla Wahl & Sypracea & $\mathrm{He}$ & \\
\hline Centaurea behen $\mathrm{L}$ & Asteraceae & $\mathrm{Ch}$ & \\
\hline Cephalaria microcephala Boiss & Caprifoliaceae & Th & \\
\hline Chrozophora tinctoria (L.) A.Juss & Euphorbiaceae & Th & \\
\hline Eremopyrom sp. & Gramineae & Th & \\
\hline Eryngium billardierei F.Delaroche & Asteraceae & $\mathrm{He}$ & \\
\hline Juncus inflexus & Juncaceae & $\mathrm{Ch}$ & \\
\hline Fagonia indica Burm.f & Zygophyllaceae & $\mathrm{He}$ & \\
\hline Halanthium rarifolium K. Koch & Amaranthaceae & Th & * \\
\hline Hammada salicornica (Moq.) Iljin & Amaranthaceae & $\mathrm{Ch}$ & * \\
\hline Herniaria hirsuta $\mathrm{L}$ & Caryophyllaceae & Th & \\
\hline Hordeum spp. & Gramineae & Th & \\
\hline Lasiopogon muscoides (Desf.) DC & Asteraceae & Th & \\
\hline Limonium stocksee L. Bolus & Plumbaginaceae & Th & \\
\hline Launaea mucronata (Forssk.) Muschl & Asteraceae & $\mathrm{Ch}$ & \\
\hline Pennisetum divisum (Forssk. ex J.F.Gmel.) Henrard & Gramineae & $\mathrm{He}$ & \\
\hline Plantago boissieri Hausskn. \& Bornm & Plantaginaceae & $\mathrm{He}$ & \\
\hline Plantago arenaria Waldst. \& Kit & Plantaginaceae & Th & \\
\hline Outreya carduiformis Jaub. \& Spach & Asteraceae & Th & \\
\hline Pycnocyla nodiflora Decne. ex Boiss & Asteraceae & $\mathrm{He}$ & \\
\hline Reaumuria stocksii Boiss & Tamaricaceae & $\mathrm{He}$ & * \\
\hline Scandix spp. & Apiaceae & Th & \\
\hline Seidlitzia rozmarinus Bunge ex Boiss & Amaranthaceae & $\mathrm{Ch}$ & * \\
\hline Scabiosa olivieri Coult & Caprifoliaceae & Th & \\
\hline Salsola imbricat Forssk & Amaranthaceae & $\mathrm{Ch}$ & * \\
\hline Schimpera arabica Hochst. \& Steud & Brassicaceae & Th & \\
\hline Suaeda vermiculata Forssk. ex J.F.Gmel & Amaranthaceae & Th & * \\
\hline Tamarix sp. & Tamaricaceae & $\mathrm{Ph}$ & * \\
\hline
\end{tabular}

*These species are halophytes

Life form: Th Therophytes, Ge geophytes, Phphanerophytes, Ch chamaephytes and He hemicryptophytes significant difference between three vegetation groups through time (Sig. <0.001). In fact, many soil factors have changed over time due to changes in MR and fluctuations in humidity (especially WT) in this area.
MR, WT and soil characteristics and vegetation revealed significant relationships. The cumulative percentage variances of vegetation characteristics-environment relation for axes of CCA were 16.20, 22.4, 20.75 and $18.44,28.40$ and 25.85 during April, June and September 


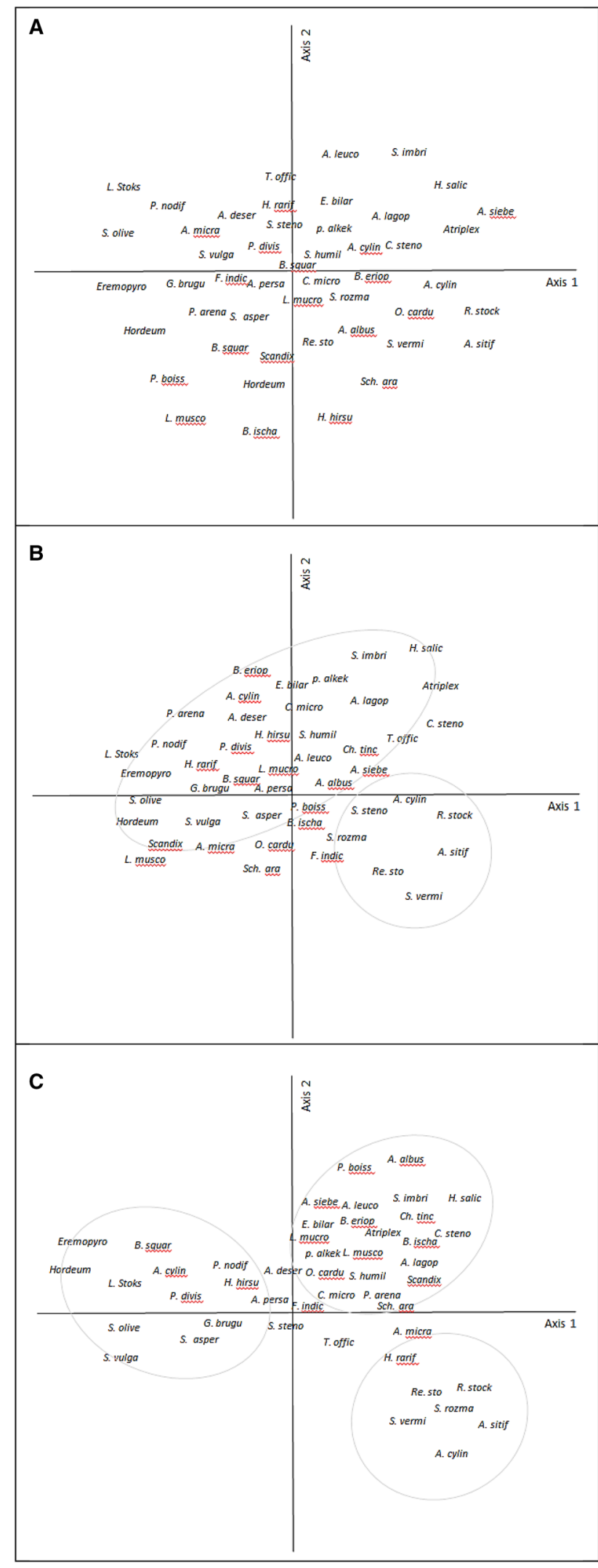

Fig. 2 DCA two-dimensional ordination (TWINSPAN groups) for species distribution in April (a), Jun (b) and September (c)
Table 2 Mean value $( \pm S D)$ of soil variables in different vegetation groups in study area

\begin{tabular}{|c|c|c|c|c|}
\hline \multirow[t]{2}{*}{ Variable } & \multicolumn{3}{|c|}{ Vegetation groups } & \multirow[t]{2}{*}{ Sig. } \\
\hline & Grasses & Non-Grasses & Halophytes & \\
\hline $\mathrm{pH}_{1}^{*}$ & $7.7 \pm 0.3^{b}$ & $7.9 \pm 0.5^{\mathrm{ab}}$ & $8.1 \pm 0.4^{\mathrm{a}}$ & $0.034^{*}$ \\
\hline $\mathrm{pH}_{2}$ & $7.4 \pm 0.4^{\mathrm{a}}$ & $7.8 \pm 0.2^{\mathrm{a}}$ & $7.9 \pm 0.3^{a}$ & $0.354^{\mathrm{ns}}$ \\
\hline $\mathrm{SP}_{1}$ & $31.2 \pm 8.0^{b}$ & $31.2 \pm 8.0^{b}$ & $37.0 \pm 10.0^{\mathrm{a}}$ & $0.032^{*}$ \\
\hline $\mathrm{SP}_{2}$ & $34.4 \pm 7.5^{\mathrm{b}}$ & $35.5 \pm 7.5^{b}$ & $39.6 \pm 10.8^{a}$ & $0.033^{*}$ \\
\hline $\mathrm{K}_{1}$ & $140.0 \pm 7.5^{\mathrm{a}}$ & $133.0 \pm 21.0^{\mathrm{ab}}$ & $121.0 \pm 18.0^{b}$ & $0.024^{*}$ \\
\hline $\mathrm{K}_{2}$ & $106.8 \pm 7.5^{\mathrm{a}}$ & $108.0 \pm 31.0^{\mathrm{a}}$ & $78.6 \pm 13.0^{b}$ & $0.013^{* *}$ \\
\hline$(\mathrm{CaSO} 4)_{1}$ & $6.9 \pm 1.0^{\mathrm{ab}}$ & $5.4 \pm 1.0^{b}$ & $7.1 \pm 0.8^{a}$ & $0.005^{* *}$ \\
\hline$(\mathrm{CaSO} 4)_{2}$ & $7.2 \pm 1.2^{\mathrm{ab}}$ & $6.0 \pm 2.0^{b}$ & $8.1 \pm 1.2^{\mathrm{a}}$ & $0.044^{*}$ \\
\hline $\mathrm{MC}_{1}$ & $22.8 \pm 7.4^{b}$ & $27.5 \pm 6.0^{\mathrm{ab}}$ & $32.5 \pm 10.4^{\mathrm{a}}$ & $0.030^{*}$ \\
\hline $\mathrm{MC}_{2}$ & $28.4 \pm 8.2^{b}$ & $31.0 \pm 7.0^{b}$ & $38.2 \pm 14.7^{\mathrm{a}}$ & $0.032^{*}$ \\
\hline $\mathrm{EC}_{1}$ & $47.4 \pm 8.5^{b}$ & $47.0 \pm 8.0^{b}$ & $69.0 \pm 10.0^{\mathrm{a}}$ & $0.003^{* *}$ \\
\hline $\mathrm{EC}_{2}$ & $35.0 \pm 8.8^{b}$ & $34.4 \pm 9.0^{b}$ & $52.4 \pm 11.0^{\mathrm{a}}$ & $0.004^{* *}$ \\
\hline $\mathrm{OM}_{1}$ & $1.7 \pm 0.4^{b}$ & $1.5 \pm 0.5^{\mathrm{b}}$ & $1.9 \pm 0.8^{\mathrm{a}}$ & $0.046^{*}$ \\
\hline $\mathrm{OM}_{2}$ & $1.0 \pm 0.5^{\mathrm{a}}$ & $1.1 \pm 0.6^{\mathrm{a}}$ & $1.1 \pm 0.4^{\mathrm{a}}$ & $0.084^{\mathrm{ns}}$ \\
\hline T.N.V 1 & $33.0 \pm 8.0^{\mathrm{a}}$ & $32.5 \pm 7.0^{\mathrm{a}}$ & $36.0 \pm 10.0^{\mathrm{a}}$ & $0.077^{\mathrm{ns}}$ \\
\hline T.N.V 2 & $36.2 \pm 9.0^{\mathrm{ab}}$ & $34.0 \pm 8.2^{b}$ & $44.0 \pm 12.0^{\mathrm{a}}$ & $0.031^{*}$ \\
\hline $\mathrm{Na}_{1}$ & $188.0 \pm 31.0^{b}$ & $153.0 \pm 33.5^{c}$ & $298.0 \pm 44.0^{\mathrm{a}}$ & $0.001^{* *}$ \\
\hline $\mathrm{Na}_{2}$ & $144.0 \pm 26.0^{b}$ & $136.0 \pm 21.0^{c}$ & $215.5 \pm 32.0^{\mathrm{a}}$ & $0.002^{* *}$ \\
\hline $\mathrm{MgCa}_{1}$ & $37.0 \pm 8.0^{b}$ & $36.4 \pm 7.0^{b}$ & $44.0 \pm 11.0^{\mathrm{a}}$ & $0.041^{*}$ \\
\hline $\mathrm{MgCa}_{2}$ & $31.0 \pm 5.0^{\mathrm{b}}$ & $30.0 \pm 6.2^{b}$ & $39.0 \pm 10.0^{\mathrm{a}}$ & $0.043^{*}$ \\
\hline $\mathrm{SAR}_{1}$ & $77.0 \pm 14.0^{\mathrm{ab}}$ & $73.0 \pm 12.2^{\mathrm{b}}$ & $88.0 \pm 15.0^{\mathrm{a}}$ & $0.033^{*}$ \\
\hline $\mathrm{SAR}_{2}$ & $52.0 \pm 13.5^{\mathrm{b}}$ & $65.0 \pm 11.8^{\mathrm{ab}}$ & $71.0 \pm 12.5^{\mathrm{a}}$ & $0.031^{*}$ \\
\hline
\end{tabular}

*These species are halophytes

$\mathrm{pH}_{1}=\mathrm{pH}$ in depth $2-20 \mathrm{~cm}, \mathrm{pH}_{2}=\mathrm{pH}$ in depth $20-80 \mathrm{~cm}$

Table 3 Eigenvalues and vegetation characteristics-environmental variables correlations of the first two CCA axes

\begin{tabular}{llcc}
\hline & Time & Axis 1 & Axis 2 \\
\hline Eigenvalues & April & 0.76 & 0.72 \\
& June & 0.58 & 0.54 \\
& September & 0.69 & 0.65 \\
Vegetation characteristics- envi- & April & 0.66 & 0.65 \\
ronment correlations & June & 0.60 & 0.61 \\
& September & 0.74 & 0.72 \\
Cumulative percentage variance & April & 16.20 & 18.44 \\
& June & 22.42 & 28.40 \\
& September & 20.75 & 25.85 \\
$P$-value & April & $0.004^{* *}$ & $0.006^{* *}$ \\
& June & $0.028^{*}$ & $0.034^{*}$ \\
& September & $0.021^{* *}$ & $0.012^{* *}$ \\
\hline
\end{tabular}

*These species are halophytes

for axes 1 and 2, respectively (Table 3). Also, the vegetation-environment correlations calculated for by the first two axes of CCA were significant $(P$-value $<0.05)$ ranging $0.65-0.72$ (Table 3 ) where the highest and lowest 
correlations between vegetation and environmental variables were in beginning/end and middle of the growing season, respectively.

Based on Table 4, there was a significant relationship between environmental variables and vegetation characteristics that changed during the growing season. In areas with greater height (higher MR), variables of WT, $M C_{1}$ (moisture content in $0-20 \mathrm{~cm}$ depth of soil), $\mathrm{MC}_{2}, \mathrm{Na}_{2}$ and $\mathrm{SAR}_{2}$ showed the highest specific value that was severely changed through the growing season.

Figure 3 shows the ecological relationships between vegetation and environmental variables at the beginning, middle and end of the growing season. Based on the CCA diagram, the relationship between vegetation characteristics and environmental factors varied at different times. The relationship between vegetation characteristics and factors, i.e., SAR, Na, WT and MR fluctuations has changed dramatically over time. At the beginning of the growing season (April), factors of MR had the most significant relation to cover and density of grasses (Eg.Value $=0.71$ ). Also, factors of $M R, M C_{1,2}$ and $\mathrm{SP}_{1,2}$ also showed a relatively high correlation with cover and density of grasses (CG, DG) and non-grasses/forbs CNG, DNG) species. In fact, the percentage of vegetation change at different altitudes varied throughout the year. Moreover, due to the decrease moisture in soil, MR and WT received new eigenvalue at the end of the growing season in June and September (Table 2).

Evaluation of the density of annual and perennial species showed significant changes under MR. Generally, the highest density for both annual and perennial species was observed in MR of +50 to $+100 \mathrm{~cm}$. Perennial species had more tolerance to MR and WT fluctuation. Halophytes species also showed significant change in relation to MRs fluctuation. Generally, density and canopy cover had the most significant differences from the highest to lowest points of MRs. MR of $+50 \mathrm{~cm}$ had more species (in number and life form) through the year. Halophytes of S. imbricata, A. leucoclada, A. lagopoides, S. vermiculata were the most stable species in this area. However, the most change has been observed in annual species under environmental variables.

Richness and diversity indices under MR changes are shown in Fig. 4. Based on the results, flat points $(M R=0)$ and hollows $(M R=-50 \mathrm{~cm})$ under highest effects of WT fluctuations had the lowest diversity and hummocks
Table 4 Correlation coefficients between environmental variables and CCA axes

\begin{tabular}{|c|c|c|c|c|c|c|}
\hline \multirow[t]{2}{*}{ Variable } & \multicolumn{2}{|l|}{ April } & \multicolumn{2}{|l|}{ June } & \multicolumn{2}{|c|}{ September } \\
\hline & Axis 1 & Axis 2 & Axis 1 & Axis 2 & Axis 1 & Axis 2 \\
\hline MR & 0.48 & 0.71 & 0.21 & 0.50 & -0.31 & 0.74 \\
\hline WT & -0.36 & -0.32 & 0.09 & 0.58 & -0.36 & 0.32 \\
\hline $\mathrm{pH} 1^{*}$ & 0.00 & 0.18 & 0.00 & 0.20 & 0.01 & 0.03 \\
\hline $\mathrm{pH}_{2}$ & 0.17 & 0.21 & 0.12 & 0.11 & 0.08 & 0.09 \\
\hline $\mathrm{SP}_{1}$ & 0.24 & 0.33 & 0.10 & 0.33 & 0.02 & 0.21 \\
\hline $\mathrm{SP}_{2}$ & 0.38 & 0.26 & 0.19 & 0.22 & 0.14 & 0.10 \\
\hline $\mathrm{K}_{1}$ & 0.15 & 0.45 & 0.11 & 0.03 & 0.08 & 0.00 \\
\hline $\mathrm{K}_{2}$ & 0.21 & 0.01 & 0.02 & 0.13 & 0.03 & 0.03 \\
\hline$(\mathrm{CaSO} 4)_{1}$ & -0.11 & 0.00 & -0.25 & -0.01 & -0.25 & 0.11 \\
\hline$(\mathrm{CaSO} 4)_{2}$ & -0.18 & 0.15 & -0.25 & -0.11 & -0.25 & -0.01 \\
\hline$M C_{1}$ & 0.21 & 0.66 & 0.27 & 0.28 & 0.45 & 0.20 \\
\hline $\mathrm{MC}_{2}$ & 0.48 & 0.49 & 0.32 & 0.20 & 0.32 & -0.19 \\
\hline $\mathrm{EC}_{1}$ & 0.00 & 0.40 & -0.02 & 0.24 & 0.00 & 0.26 \\
\hline $\mathrm{EC}_{2}$ & 0.00 & 0.25 & -0.02 & 0.10 & 0.07 & 0.07 \\
\hline $\mathrm{OM}_{1}$ & 0.21 & 0.12 & 0.21 & 0.23 & 0.00 & 0.00 \\
\hline $\mathrm{OM}_{2}$ & 0.16 & 0.13 & 0.01 & 0.00 & 0.47 & 0.11 \\
\hline T.N.V & -0.17 & -0.19 & -0.12 & -0.21 & 0.20 & -0.24 \\
\hline T.N.V 2 & -0.21 & -0.05 & -0.19 & -0.17 & 0.20 & -0.17 \\
\hline $\mathrm{Na}_{1}$ & 0.02 & -0.11 & 0.06 & 0.00 & 0.24 & -0.12 \\
\hline $\mathrm{Na}_{2}$ & 0.19 & -0.15 & 0.22 & -0.13 & 0.38 & -0.33 \\
\hline $\mathrm{MgCa}_{1}$ & -0.16 & -0.20 & -0.11 & -0.08 & 0.20 & -0.12 \\
\hline $\mathrm{MgCa}_{2}$ & 0.00 & 0.01 & 0.01 & -0.17 & 0.03 & -0.11 \\
\hline $\mathrm{SAR}_{1}$ & 0.02 & -0.20 & 0.03 & 0.21 & 0.31 & -0.52 \\
\hline $\mathrm{SAR}_{2}$ & 0.17 & 0.02 & 0.18 & -0.04 & 0.33 & -0.35 \\
\hline
\end{tabular}

*Factors with no. 1 are related to the first depth of the soil and factors with no. 2 are related to the second depth of the soil 

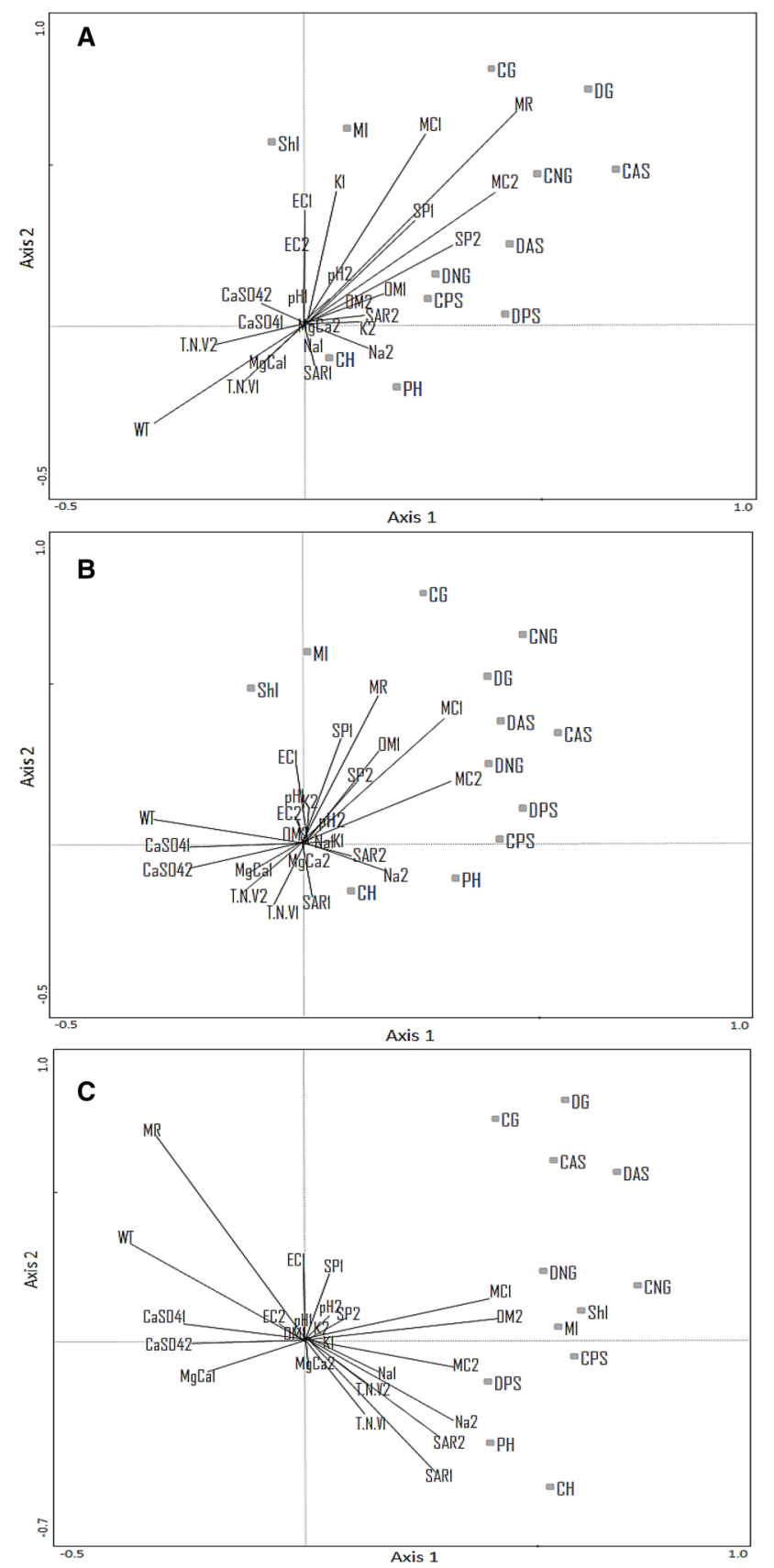

Fig. 3 CCA two-dimensional ordination diagram for vegetation characteristics and environmental variables in April (a), Jun (b) and September (c). Abbreviations: CG=Cover of Grasses; DG = Density of Grasses; CNG = Cover of Non-Grasses (forbs); DNG=Density of Non-Grasses; DAS = Density of Annual Species/plot; DPS=Density of Perennial Species/plot; $\mathrm{Ml}=$ Margalef Index; Shl=Shannon Index; $\mathrm{PH}=$ Percentage of Halophytes; $\mathrm{CH}=$ Cover of Halophytes

$(+50 \mathrm{~cm})$ had the highest diversity and richness (Fig. 5). Generally, annual species have the most effect on changing diversity indices through the year. These species grow at the beginning of the growing season and dry out again with changes in environmental variables, i.e., salinity.

\section{Discussion}

Ecological analysis provides evidence about the environmental resources and environmental factors affecting them [29].Both MR and WT influenced vegetation in this coastal desert with heavy textured saline soil. Generally, MRs of -50.0 and $+100.0 \mathrm{~cm}$ affected severely by WT had the lowest perennial species cover through the year. In fact, changes in MR and WT create specific environmental conditions for plants in this area. These conditions create highly complex biogeochemistry and play as a key factor in the formation of vegetation groups $[8,30]$. MR is considered to be the primary influence on vegetation of regional and landscape scales [31, 32]. Therefore, knowledge of environmental factors affecting vegetation can be useful for efficient ecological management of the land [33,34].

In this area, MR and WT both had a significant effect on the vegetation characteristics. Based on the results, more heterogeneity significantly changed diversity indices of Shannon and Margalef indices ( also cover and density of species) in which the least value has been observed at the lowest (hollows) and higher (hummocks) points of soil surfaces (Sig. $<0.05$ ). It seems that in the highest and lowest points ( $M R=-50$ and +100$)$, due to the high effects of WT fluctuations and changes in soil conditions, vegetation had the most changes over time. Therefore, in areas with heavy saline soil, vegetation dynamics are controlled by MR and WT fluctuations and a greater number of ecological niches and a highly diverse species composition will result $[4,35]$ due to the changes in soil characteristics [2].

MRs of + 50.0 with lowest WT change had the highest diversity. Plant diversity strongly influences ecosystem functions and reflects ecosystem conditions[36, 37]. On one hand, species diversity and ecosystem stability are closely linked under WT and MR fluctuations[38]. Such this pattern in vegetation composition and diversity also has been observed in wetlands under hydrologic condition changes [39]. Therefore, due to unstable conditions, higher and lower MR had the lowest diversity.

In general, vegetation is influenced by different topographic factors at different scales [11, 40], and, therefore, MRs may have marginal effects, so the change in solar radiation may influence local vegetation patterns through changes in soil moisture, especially at local scale $[11,14,41]$. However, due to the flat surface in this area, it can be concluded that MR and WT both change the 

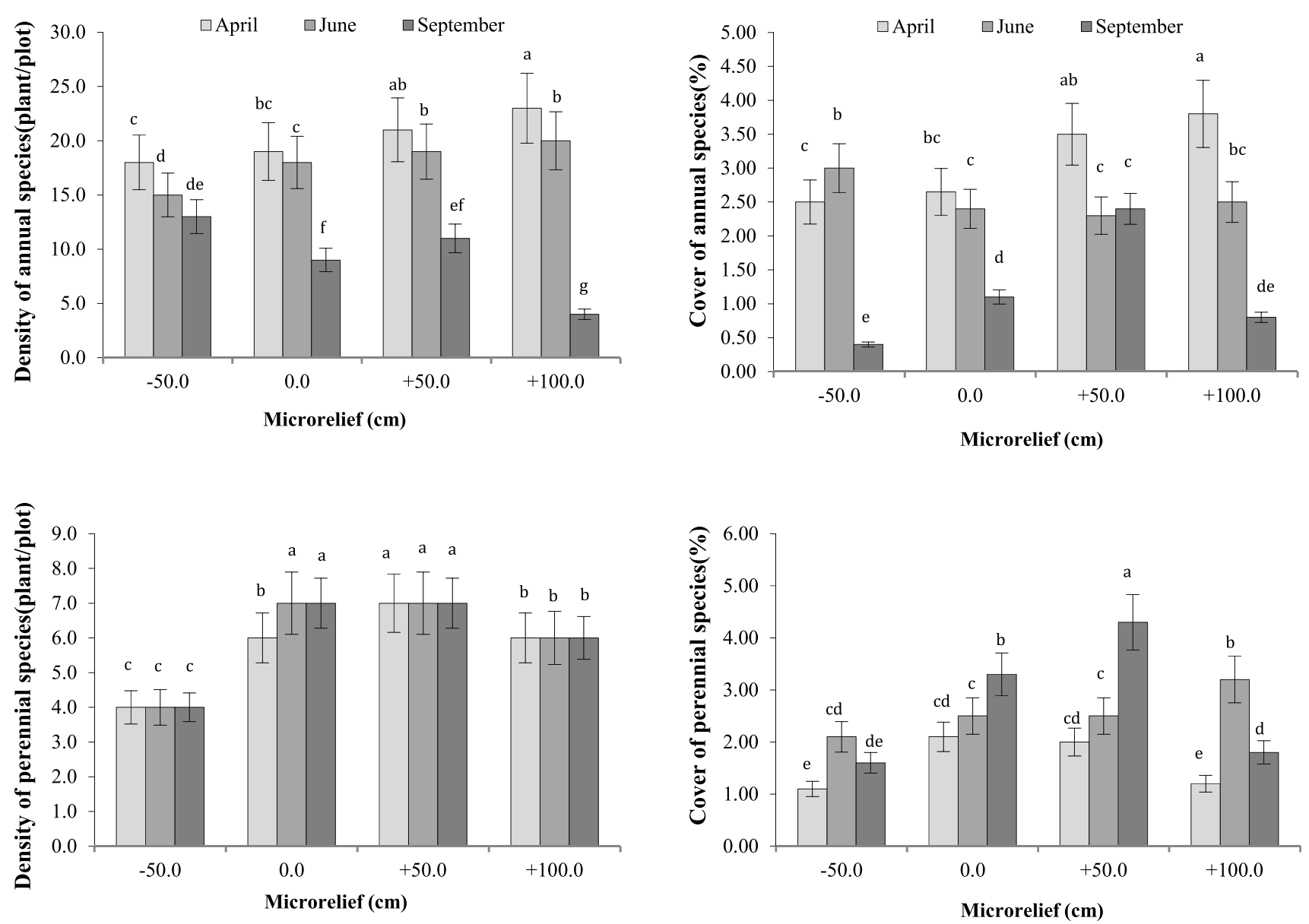

Fig. 4 Changes in density and cover of annual and perennial species in relation to MR through growing season

soil conditions and have led to create specific vegetation dynamics through the year.

In these areas, changes in WT and MR at first influence soil moisture and then salt concentration. These changes are important factors in changing plant available nutrients and microclimate [4, 42,43]. Similarly, it has been mentioned that environmental differences observed between hummocks and hollows can be explained by differences in water logging regimes due to elevation differences. In fact, hollows have fewer herbaceous species in comparison with hummocks that may be due to hollow's anoxic soils [8]. Therefore, due to have different humidity, hummocks and hollows of MR are important for vegetation [41] especially for grasses and annual species at the beginning of the growing season.

Moreover, flat surfaces (MR $=0-50 \mathrm{~cm})$ had higher perennial species through the growing season. These facts are in accordance with previous study in arid land of western Australia. They reported that woody species are associated with hummocks rather than hollows [26]. In this saline area, the most perennial species were halophytes such as S. imbricata, A. leucoclada, L. stocksee, A. lagopoides that created a permanent cover through the year. Halophytes have the ability to separate and exclude excess salts, the vesiculated trichomes or salt glands of xerohalophytic plants have been analogized to miniature desalinization machines [44], therefore, the existence of spatialtemporal gradients of salinity and edaphic factors, i.e., $\mathrm{Na}$, EC are the most important factors that influence plant distribution [45].

The MR affects ecosystem function by affecting oxygen penetration, nutrient availability, rates of decomposition and herbaceous plant species distributions [8] and therefore, have a great influence on vegetation dynamics [41]. Compared to hollows, hummocks have less solutes through time and markedly accelerates ecological succession and promotes enhanced plant community at the time of reclamation [46]. The MRs influences vegetation under any climate[47]. Another researcher also observed a gradual pattern in diversity and reported that MRs is the main driver of changes in the vegetation composition in the Siberian Arctic[7].

The MR influence the edaphic process and understanding and qualifying the effects of this is essential 

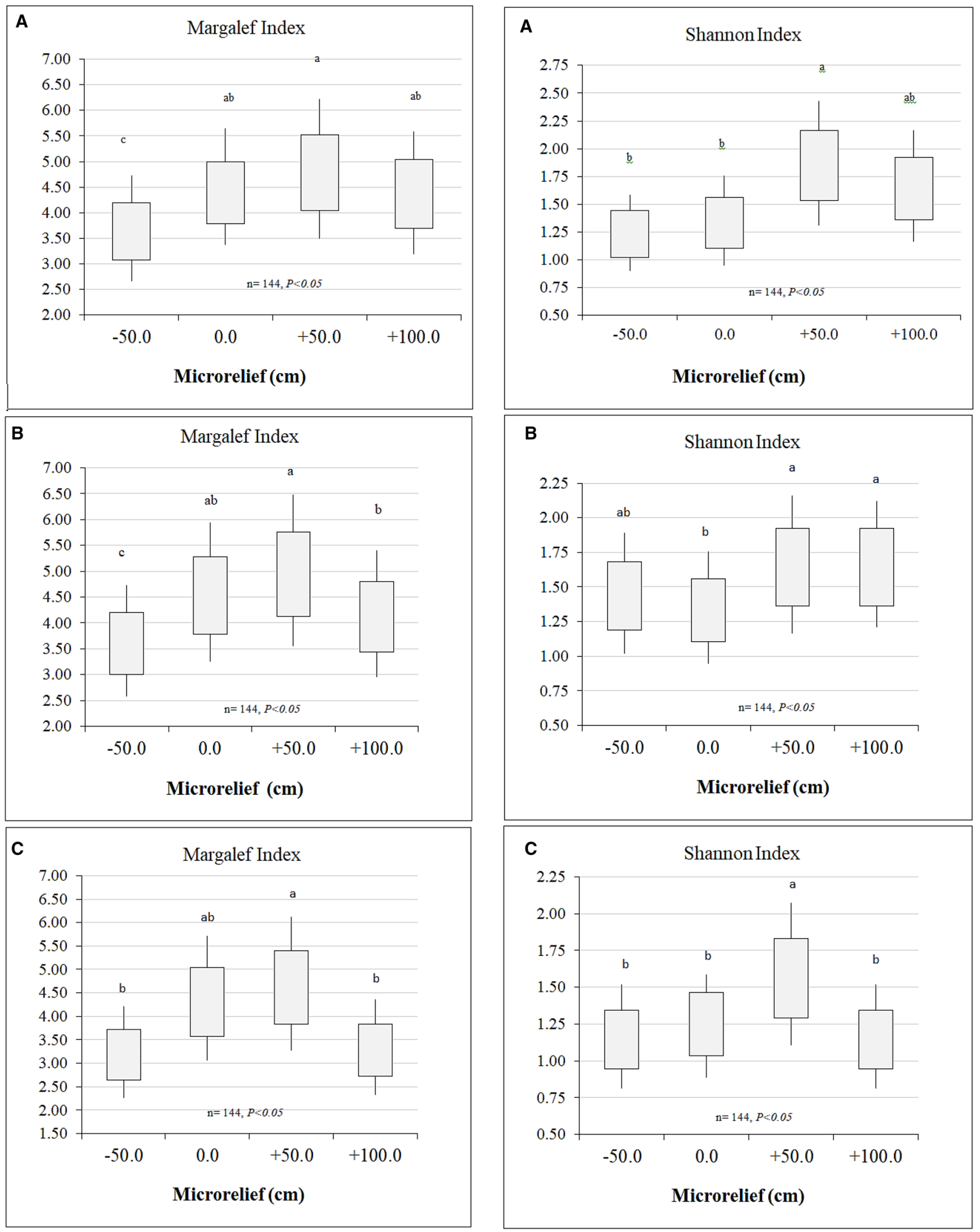

Fig. 5 Margalef (richness) and Shannon (diversity) indices in relation to MR in April (a), June (b) and September (c) 
for the evaluation of environmental changes. Compared to flat areas, lands with more MR had worse porosity, higher salinity-alkalinity ratios and lower nutrient levels. These changes affect the soil conditions for plant growth and establishment [48]. Also, MR of the soil surface in the Bellsund region is accompanied by soils of different chemical properties, and with different plant covers[47].

Furthermore, WT fluctuation severely influences vegetation through time in heavy saline soils. Another study described locations with a change in WT in the high rainfall season and even in the low rainfall season in relation to salinity significantly changed cover and biomass in Puccinellia ciliata [49]. This change in vegetation characteristics also reported in Tuzluca especially in areas with high WT levels [50]. Similarly, it has been reported flat areas with minimum MR in wetlands, supported higher plant diversity and species richness than hummock or hollow points [1].

In saline area, however, WT depth is the major factor to control soil salinity [51]. In investigation, the vegetation under WT fluctuations in New Zealand, species diversity was affected by the WT changes in which species richness was different through the year under WT fluctuations[52]. Previous study also reported that the lower WT was apparently one of the major attributes to the low plant species diversity in arid regions [38]. They disclosed that for instant Shannon-Weiner index was found to vary in a range from 0.53 to 1.93 . Generally, in this area with heavy saline soil, all edaphic properties have been affected by MR and WT fluctuations.

WT depth varies in time and space based on pedological and hydrological processes [53], and the processes of macroaggregation and structural porosity are enhanced under higher soil surface roughness [54]. Moreover, very small changes in MR caused significant changes in moisture and other soil properties. All these fluctuations along with the soil surface roughness promote soil biota activity, which play an important role in the rehabilitation of soil surfaces [54].

In general, a suitable environment for organisms is mainly defined by soil physical and chemical properties [55]. However, in general, soils may act at different spatial and temporal scales and change vegetation [56], their attributes together with other habitat and microhabitat characteristics play an important role in biology communities [3]. Moreover, MR and WT fluctuations influence soil physical and chemical characteristic that can play an important role in vegetation dynamics, especially in coastal areas with silty loam saline soils. In these areas, vegetation plays a significant role in landscape ecology and protect human lives [57] and its relation with MR and WT fluctuations should be considered for rehabilitation programs [58].

\section{Conclusions}

The MR and WT fluctuations significantly changed vegetation dynamics by changing the soil characteristics in silty loam saline soil of a coastal area. Soil moisture and solutes concentration, i.e., SAR, Na were strongly changed under MR and WT fluctuations. Vegetation cover, density, richness and diversity indices severely influenced by seasonal WT fluctuations and MR changes. Generally, minimum changes in MR and/or WT influence the vegetation in coastal silty loam saline soils, where ruggedness point in the range of $0-50 \mathrm{~cm}$ had more perennial species and higher diversity. Moreover, the changes in plant life forms such as grasses, forbs and halophytes as well as annual and perennial species were different under WT and MR fluctuations. These results suggest that the ecological management and biological practices such as plant cultivation should be done based on the MR and WT characteristics in silty loam saline soils of coastal areas.

Acknowledgements We are grateful to Eng. Asadollahi and Dr. Yazdanshenas for their helpful discussion and comments. We also thank Dr. Tavili and Dr. Asadpour for their help during research. The authors also thank to the laboratory section for their support in soil analysis.

\section{Compliance with ethical standards}

Conflict of interest The authors declared that they have no conflict of interest.

Open Access This article is licensed under a Creative Commons Attribution 4.0 International License, which permits use, sharing, adaptation, distribution and reproduction in any medium or format, as long as you give appropriate credit to the original author(s) and the source, provide a link to the Creative Commons licence, and indicate if changes were made. The images or other third party material in this article are included in the article's Creative Commons licence, unless indicated otherwise in a credit line to the material. If material is not included in the article's Creative Commons licence and your intended use is not permitted by statutory regulation or exceeds the permitted use, you will need to obtain permission directly from the copyright holder. To view a copy of this licence, visit http://creativecommons .org/licenses/by/4.0/.

\section{References}

1. Moser K, Ahn C, Noe G (2007) Characterization of microtopography and its influence on vegetation patterns in created wetlands. Wetlands. https://doi.org/10.1672/02775212(2007)27[1081:COMAII]2.0.CO;2 
2. Bennett JA, Maherali H, Reinhart KO et al (2017) Plant-soil feedbacks and mycorrhizal type influence temperate forest population dynamics. Science 355:181-184

3. de Abreu Pestana LF, de Souza ALT, Tanaka MO et al (2020) Interactive effects between vegetation structure and soil fertility on tropical ground-dwelling arthropod assemblages. Appl Soil Ecol 155:103624

4. Leutner BF, Steinbauer MJ, Müller CM et al (2012) Mosses like it rough-growth form specific responses of mosses, herbaceous and woody plants to micro-relief heterogeneity. Diversity. https ://doi.org/10.3390/d4010059

5. Wolf KL, Ahn C, Noe GB (2011) Microtopography enhances nitrogen cycling and removal in created mitigation wetlands. Ecol Eng 37:1398-1406. https://doi.org/10.1016/j.ecole ng.2011.03.013

6. Redelstein R, Dinter T, Hertel D, Leuschner C (2018) Effects of inundation nutrient availability and plant species diversity on fine root mass and morphology across a saltmarsh flooding gradient. Front Plant Sci 9:1-15. https://doi.org/10.3389/ fpls.2018.00098

7. Zibulski R, Herzschuh U, Pestryakova LA (2016) Vegetation patterns along micro-relief and vegetation type transects in polygonal landscapes of the Siberian Arctic. J Veg Sci. https:// doi.org/10.1111/jvs.12356

8. Courtwright J, Findlay SEG (2011) Effects of microtopography on hydrology, physicochemistry, and vegetation in a tidal swamp of the hudson river. Wetlands 31:239-249. https://doi.org/10.1007/ s13157-011-0156-9

9. Seo $\mathrm{CH}$, Furukawa K, Montagne $\mathrm{K}$ et al (2011) The effect of substrate microtopography on focal adhesion maturation and actin organization via the RhoA/ROCK pathway. Biomaterials 32:9568-9575. https://doi.org/10.1016/j.biomateria Is.2011.08.077

10. Endara MJ, Jaramillo JL (2011) The influence of microtopography and soil properties on the distribution of the speciose genus of trees, Inga (Fabaceae: Mimosoidea), in Ecuadorian Amazonia. Biotropica 43:157-164

11. Zhou Q, Wei X, Zhou X et al (2019) Vegetation coverage change and its response to topography in a typical karst region: the Lianjiang River Basin in Southwest China. Environ Earth Sci 78:191

12. Moeslund JE, Arge L, Bøcher PK et al (2013) Topography as a driver of local terrestrial vascular plant diversity patterns. Nordic J Bot 31:129-144. https://doi.org/10.111 1/j.1756-1051.2013.00082.x

13. Zalatnai M, Körmöczi L (2004) Fine-scale pattern of the boundary zones in alkaline grassland communities. Commun Ecol. https://doi.org/10.1556/ComEc.5.2004.2.11

14. Kavgaci A, Čarni A, Başaran S et al (2010) Vegetation of temporary ponds in cold holes in the Taurus mountain chain (Turkey). Biologia. https://doi.org/10.2478/s11756-010-0053-3

15. Moeslund JE, Arge L, Bøcher PK et al (2011) Geographically comprehensive assessment of salt-meadow vegetation-elevation relations using LiDAR. Wetlands. https://doi.org/10.1007/s1315 7-011-0179-2

16. Økland RH, Rydgren $\mathrm{K}, \varnothing$ kland $\mathrm{T}$ (2008) Species richness in boreal swamp forests of SE Norway: the role of surface microtopography. J Veg Sci. https://doi.org/10.3170/2007-8-18330

17. Branton C, Robinson DT (2019) Quantifying topographic characteristics of wetlandscapes. Wetlands 1-17

18. Jeppesen E, Brucet S, Naselli-Flores L et al (2015) Ecological impacts of global warming and water abstraction on lakes and reservoirs due to changes in water level and related changes in salinity. Hydrobiologia 750:201-227. https://doi.org/10.1007/ s10750-014-2169-x
19. IPCC (2014) Climate Change 2014: Mitigation of Climate Change. Summary for Policymakers and Technical Summary

20. Reddy KR, DeLaune RD (2008) Biogeochemistry of wetlands: Science and applications

21. Kögel-Knabner I, Amelung W, Cao Z, et al (2010) Biogeochemistry of paddy soils. Geoderma

22. Lipson DA, Zona D, Raab TK et al (2012) Water-table height and microtopography control biogeochemical cycling in an Arctic coastal tundra ecosystem. Biogeosciences 9:577-591. https:// doi.org/10.5194/bg-9-577-2012

23. Deegan BM, White SD, Ganf GG (2007) The influence of water level fluctuations on the growth of four emergent macrophyte species. Aquat Bot 86:309-315. https://doi.org/10.1016/j.aquab ot.2006.11.006

24. Rahman A, Ahmed KM, Butler AP, Hoque MA (2018) Influence of surface geology and micro-scale land use on the shallow subsurface salinity in deltaic coastal areas: a case from southwest Bangladesh. Environ Earth Sci 77:423

25. Taylor M, Krüger N (2019) Changes in salinity of a clay soil after a short-term salt water flood event. Geoderma Regional. https ://doi.org/10.1016/j.geodrs.2019.e00239

26. Mott JJ, McComb AJ (1974) Patterns in annual vegetation and soil microrelief in an arid region of Western Australia. J Ecol. https://doi.org/10.2307/2258884

27. Hegazy AK, Hammouda O, Lovett-Doust J, Gomaa NH (2009) Variations of the germinable soil seed bank along the altitudinal gradient in the northwestern Red Sea region. Acta Ecol Sin. https://doi.org/10.1016/j.chnaes.2009.04.004

28. Kocatacs A (1992) Ekoloji ve Çevre Biyolojisi, Ege Üniv. Matbaasi, Izmir, 564s

29. Urooj R, Ahmad SS (2019) Spatio-temporal ecological changes around wetland using multispectral satellite imagery in AJK. Pak SN Appl Sci 1:714

30. Day RH, Williams TM, Swarzenski CM (2007) Hydrology of tidal freshwater forested wetlands of the southeastern United States. In: Ecology of tidal freshwater forested wetlands of the Southeastern United States. Springer, pp 29-63

31. Solomou AD, Sfougaris Al (2015) Determinants of woody plant species richness in abandoned olive grove ecosystems and maquis of Central Greece. Commun Soil Sci Plant Anal 46:317-325

32. Peng W, Song T, Zeng F et al (2012) Relationships between woody plants and environmental factors in karst mixed evergreen-deciduous broadleaf forest, southwest China. J Food Agric Environ 10:890-896

33. Rodriguez-Rojo MP, Pérez-Badia R (2009) Contribution to the knowledge of plant diversity and conservation of natural areas in la Manchuela Conquense (Spain). Acta Bot Gallica 156:89-103

34. Lishawa SC, Lawrence BA, Albert DA, Tuchman NC (2015) Biomass harvest of invasive Typha promotes plant diversity in a Great Lakes coastal wetland. Restor Ecol 23:228-237. https:// doi.org/10.1111/rec.12167

35. Debski I, Burslem DFRP, Palmiotto PA et al (2002) Habitat preferences of Aporosa in two Malaysian forests: implications for abundance and coexistence. Ecology 83:2005-2018

36. Hooper DU, Chapin FS, Ewel JJ et al (2005) Effects of biodiversity on ecosystem functioning: a consensus of current knowledge. Ecol Monogr 75:3-35

37. Lange M, Eisenhauer N, Sierra CA et al (2015) Plant diversity increases soil microbial activity and soil carbon storage. Nat Commun 6:1-8

38. Chen Y, Zilliacus H, Li W et al (2006) Ground-water level affects plant species diversity along the lower reaches of the Tarim river. Western China 66:231-246. https://doi.org/10.1016/j.jarid env.2005.11.009 
39. Dee S, Korol A, Ahn C et al (2018) Patterns of vegetation and soil properties in a beaver-created wetland located on the Coastal Plain of Virginia. Landscape Ecol Eng 14:209-219

40. Kirkpatrick JB, Green K, Bridle KL, Venn SE (2014) Patterns of variation in Australian alpine soils and their relationships to parent material, vegetation formation, climate and topography. CATENA 121:186-194

41. Štícha V, Kupka I, Zahradník D, Vacek S (2010) Influence of micro-relief and weed competition on natural regeneration of mountain forests in the Šumava Mountains. J For Sci. https://doi. org/10.17221/28/2009-jfs

42. da Silva WG, Metzger JP, Bernacci LC et al (2008) Relief influence on tree species richness in secondary forest fragments of Atlantic Forest, SE, Brazil. Acta Bot Brasilica 22:589-598

43. von Suchodoletz H, Glaser B, Thrippleton T et al (2013) The influence of Saharan dust deposits on La Palma soil properties (Canary Islands, Spain). CATENA 103:44-52

44. Sookbirsingh R, Castillo K, Gill E, Chianelli RR (2010) Salt separation processes in the saltcedar tamarix ramosissima (Ledeb.). Communi Soil Sci Plant Anal. https://doi.org/10.1080/00103 621003734281

45. CANADAS SANCHEZ EVA, Jimenez M, Valle F, et al (2010) Soilvegetation relationships in semi-arid Mediterranean old fields (SE Spain): Implications for management

46. Gilland KE, McCarthy BC (2014) Microtopography influences early successional plant communities on experimental coal surface mine land reclamation. Restor Ecol 22:232-239

47. Klimowicz Z, Uziak S (1996) Arctic soil properties associated with micro-relief forms in the Bellsund region (Spitsbergen). CATENA 28:135-149

48. Zhang M, Pu L, Wang $X$ et al (2018) The effects of micro-relief on soil properties in a reclaimed eastern coastal region of China. J Earth Sci Environ Stud 3:350-360. https://doi.org/10.25177/ JESES.3.1.5

49. Jenkins S, Barrett-Lennard EG, Rengel Z (2010) Impacts of waterlogging and salinity on puccinellia (Puccinellia ciliata) and tall wheatgrass (Thinopyrum ponticum): Zonation on saltland with a shallow water-table, plant growth, and $\mathrm{Na}+$ and $\mathrm{K}+$ concentrations in the leaves. Plant Soil 329:91-104. https://doi. org/10.1007/s11104-009-0137-4
50. Öztürk M, Altay V, Altundaug E, Gücel S (2016) Halophytic plant diversity of unique habitats in Turkey: salt mine caves of Çankiri and Iugdir. In: Halophytes for Food Security in Dry Lands. Elsevier, pp 291-315

51. Sun G, Zhu Y, Ye M et al (2019) Development and application of long-term root zone salt balance model for predicting soil salinity in arid shallow water table area. Agric Water Manag 213:486-498. https://doi.org/10.1016/j.agwat.2018.10.043

52. Riis T, Hawes I (2002) Relationships between water level fluctuations and vegetation diversity in shallow water of New Zealand lakes. Aquat Bot 74:133-148

53. Ritzema HP, Heuvelink GBM, Heinen M, et al (2018) Review of the methodologies used to derive groundwater characteristics for a specific area in The Netherlands. Geoderma Regional

54. Garcia Moreno R, Burykin T, Alvarez D, Crawford JW (2012) Effect of management practices on soil microstructure and surface microrelief. Appl Environ Soil Sci

55. Tajik S, Ayoubi S, Lorenz N (2020) Soil microbial communities affected by vegetation, topography and soil properties in a forest ecosystem. Appl Soil Ecol 149:103514

56. Valtera M, Šamonil P, Svoboda M, Janda P (2015) Effects of topography and forest stand dynamics on soil morphology in three natural Picea abies mountain forests. Plant Soil 392:57-69

57. Tanaka N, Jinadasa KBSN, Mowjood MIM, Fasly MSM (2011) Coastal vegetation planting projects for tsunami disaster mitigation : effectiveness evaluation of new establishments. Reg Enviorn Change. https://doi.org/10.1007/s11355-010-0122-3

58. Tanaka N, Sasaki Y, Mowjood MIM et al (2007) Coastal vegetation structures and their functions in tsunami protection: experience of the recent Indian Ocean tsunami. Landscape Ecol Eng 3:33-45

Publisher's Note Springer Nature remains neutral with regard to jurisdictional claims in published maps and institutional affiliations. 